\title{
Effect of Selected Curing Methods on Density and Compressive Strength of Concrete for Technological Self-Reliance
}

\author{
${ }^{\star 1}$ Grace M. Amusan, ${ }^{2}$ Monsuru O. Popoola and ${ }^{3}$ Jelili. O. Shittu \\ ${ }^{1}$ Department of Civil Engineering, Olabisi Onabanjo University, Ago-Iwoye, Nigeria \\ ${ }^{2}$ Department of Civil Engineering, Moshood Abiola Polytechnic, Abeokuta, Nigeria \\ gma.research18@gmail.com | oyenolapopoola@yahoo.co.uk | shittu.jelili@mapoly.edu.ng
}

Received: 27-MAY-2021; Reviewed: 21-JUL-2021; Accepted: 10-SEP-2021

http://dx.doi.org/10.46792/fuoyejet.v6i3.650

\begin{abstract}
The quest to deliver construction projects within the shortest possible time handled many engineers to maneuver curing ages of concrete and this has been a major concern in construction industries due to associated failures of concrete members emanating from improper curing. This study therefore aimed at investigating the effect of different curing methods on density and compressive strength of concrete with a view to enhancing technological self-reliance of the nation. Concrete cube specimens $(150 \mathrm{~mm} \times 150 \mathrm{~mm} \times 150 \mathrm{~mm})$ were cast using mix ratio 1:2:4 with 0.5 water-cement ratio. The concrete specimens were cured for 28 days using open air, ponding, sprinkling and dry covering curing methods. The compressive strength and density were evaluated. The data were validated. The results showed that the compressive strength increases with increasing curing age. The respective compressive strength values obtained for ponding, sprinkling, dry covering and open-air curing methods were 22.04, 20.48, 17.28 and 16.02 respectively. The curing methods have compressive strengths in the order Ponding < sprinkling < dry covering < open air. The results of the curing methods on density were also noticed to be directly proportional to strength. Appropriate curing methods of concrete had greater impact in influencing physical and mechanical properties of concrete.
\end{abstract}

Keywords- Concrete, Curing methods, Strength, Sustainable growth

\section{INTRODUCTION}

$\mathrm{F}$ ailures in structure had been reported by several researchers, to emanate from improper curing methods during construction activities (Raheem et al., 2013; Idowu and Black, 2014; Unnithan and Anil, 2017). Curing provides concrete with sufficient moisture and temperature to aid cement hydration. Curing controls amount of moisture loss from concrete during hydration. Neville (1996) discovered proper moisture condition as critical because the hydration of the cement ceases when the relative humidity within the capillaries drops below $80 \%$. Proper curing of concrete was also reported to be crucial so as to obtain design strength and maximum durability, especially for concrete exposed to extreme environmental conditions at an early age (James et al., 2011). Research has shown that curing generally accelerates cement hydration and concrete strength gain at early age. Ramezanianpour and Malhotra (1995) and Zain et al. (2000) observed that concrete at the early age, would not gain the required strength if not well cured.

Wojcik and Fitzgarrald (2001) submitted that insufficient moisture from improper curing produced cracks, compromised strength, and reduced long-term durability. Kosmatka et al. (2002) also established that curing conserved satisfactory moisture content and temperature in concrete or mortar for sufficient period of time. Besides, Animesh (2015) agreed curing prevents loss of moisture from the concrete and maintains a favourable temperature for hydration to occur for a definite period.

\section{${ }^{*}$ Corresponding Author}

Section E- CIVIL ENGINEERING \& RELATED SCIENCES Can be cited as:

Amusan G.M., Popoola M.O. and Shittu J.O. (2021): Effect of Selected Curing Methods on Density and Compressive Strength of Concrete for Technological Self-Reliance, FUOYE Journal of Engineering and Technology (FUOYEJET), 6(3), 87-90. http://dx.doi.org/10.46792/fuoyejet.v6i3.650
Similarly, Mamlouk and Zaniewski (2006) discovered curing to possess strong influence on concrete and mortar. The results displayed curing to improve strength, volume, stability, permeability resistance and durability. Amusan and Olutoge (2014) investigated concrete curing exposure on shrinkage properties of concrete. The authors submitted that curing exposures were had greater impact on shrinkage properties of concrete. However, Mamlouk and Zaniewski (2006) observed concrete that was not cured and allowed to dry in air, to gain only $50 \%$ of the strength of continuously cured concrete. The authors further asserted concrete to reach about $60 \%$ of the strength of continuously cured concrete; if cured for only three days, whereas $80 \%$ of the strength of continuously cured concrete, for concrete cured for seven days, and for curing that stopped for some time and then resumed again, the strength gain also stopped and reactivated.

Several other factors such as quality and quantity of cement used in a mix, grading of aggregates, maximum nominal size, shape and surface texture of aggregate (Arum and Alhassan, 2005), water/cement ratios, degree of compaction (Aluko, 2005) and the presence of clayey particles and organic matter in the mix (Arum and Udoh, 2005) had equally been reported to affect strength development and durability in concrete. This paper on the contrary, is limited to concrete curing techniques.

Different curing techniques had been adopted depending on either site conditions or construction methods, ranging from the most popular water-submerged curing to moist sand, water-spray curing, polythene membrane sealing and steam curing (autoclaving). It is based on this background that the paper therefore aimed to investigate the effect of different curing methods on density and compressive strength of concrete with the view of enhancing technological self-reliance of the nation. To 
achieve this, the objectives were: to examine various curing methods and their relative effects on concrete maturation development; to evaluate the influence of different curing conditions on physical properties of concrete; and to study the effect of the curing methods on strength properties of concrete.

\section{Methodology 2.1 MATERIALS}

The materials used in this study include Ordinary Portland Cement, fine aggregate, mixing water and coarse aggregate. The properties of some of these are described below.

\subsubsection{Cement}

The cement used in mixture of this research was Ordinary Portland of Grade 43; which was in accordance to BS 12 (1996). The conforming weight of each bag of cement is 50 $\mathrm{kg}$.

\subsubsection{Aggregates}

The main aggregates type used in this research work were crushed limestone, fine sand and crushed rock coarse aggregate. The fine aggregate was well graded sharp sand from a locally available river that passes through $4.75 \mathrm{~mm}$ and retained on $2.36 \mathrm{~mm}$ sieve and the coarse aggregate was granite with a maximum aggregate size limited to $12.5 \mathrm{~mm}$ obtained from a quarry in Abeokuta, Ogun State of Nigeria.

\subsubsection{Mixing Water}

Pipe-borne water was used as mixing water. It was drinkable, clear, free from oil and apparently clean. It does not contain any substance at excessive amount that can be harmful to the concrete being produced.

\subsection{Mix Proportioning and Casting of Concrete}

A total of 36 concrete cube specimens $(150 \mathrm{~mm} \times 150 \mathrm{~mm}$ $\times 150 \mathrm{~mm}$ ) were cast using mix ratio 1:2:4 with 0.5 watercement ratio. The dry constituents namely the fine aggregates (sand) and cement were measured out and mixed thoroughly then later mixed with weighed out coarse aggregate (granite), and water was added gradually to achieve a grey uniform colour paste as mixing continued. The concrete specimens were cured for 7, 14 and 28 days using four curing methods; open air, ponding, sprinkling and dry covering methods described in section 2.3 below.

\subsection{Curing Test}

In the open-air curing test, the concrete specimens were left uncovered and kept under a shed to receive fresh air until the maturation age was reached. The second method tested was ponding, this was achieved by complete immersion of the concrete cube specimens in water at room temperature till the age of maturation. Consequently, sprinkling curing method was done by spraying water on the concrete specimen early morning before the sunrise, and evening, after the sun had set. Finally, the dry covering method was achieved by wrapping the concrete specimens with jute bags till the maturation age.

\subsection{Compressive StRENGTH TEST AND DENSITY}

The compressive strength and density were evaluated at the curing expiration age. The concrete specimens were weighed using digital weighing balance and recorded, vernier calliper was used to measure the length, width and depth of the specimen to obtain the concrete volume. The density was finally determined by finding the ratio of the concrete weight to volume.

Thereafter, compressive strength of the cube specimens was determined in accordance with BS 1881 (1983). The failure load was recorded and the compressive strength were calculated as ratio of load to that of concrete area. Figures 2 and 3 showed the concrete compressive strengths and densities, respectively.

\subsection{RESULTS AND DISCUSSION}

\subsection{PARTICLE Size Distribution.}

The particle size distribution analysis was carried out. The fine and coarse aggregate were uniformly graded. The particle size distribution curves the aggregate. samples are also illustrated in Figure 1.

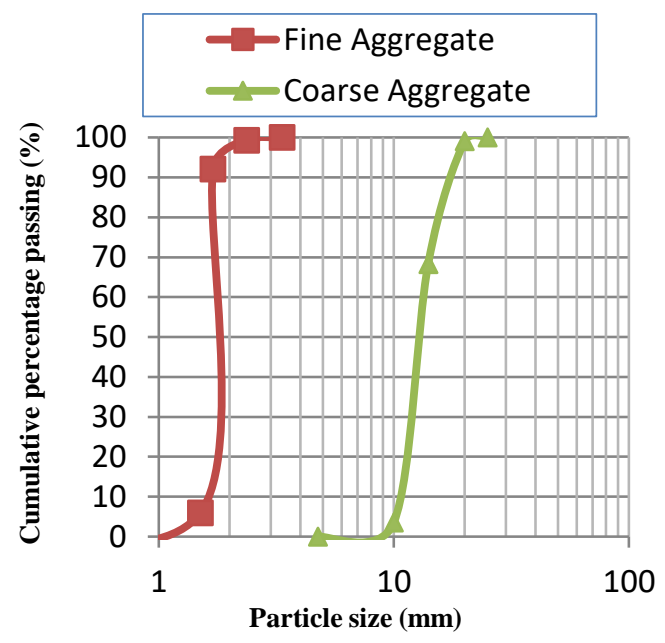

Fig. 1: Particle size distribution of aggregates

\subsection{SLUMP AND COMPACTING FACTOR RESULtS 3.2.1 Slump Test}

The concrete was found to retain its shape after removing the cone, which implied a true slump. The difference between the height of cone and height of collapse was measured, the slump gave a value of $20 \mathrm{~mm}$, which implied that, the mix required a good level of compaction for adequate workability. This was traceable to a balanced fine/ coarse aggregate and water-cement ratio.

Table 1. Slump test result

\begin{tabular}{ccc}
\hline $\begin{array}{c}\text { Height of cone } \\
(\mathbf{m m})\end{array}$ & $\begin{array}{c}\text { Height of collapse } \\
(\mathbf{m m})\end{array}$ & $\begin{array}{c}\text { Slump } \\
(\mathbf{m m})\end{array}$ \\
\hline 300 & 280 & 20 \\
\hline
\end{tabular}




\subsubsection{Compacting Factor Test}

The compacting factor result for 0.5 water-cement ratio was found to be 0.82 . The compacting factor result was more than $70 \%$ range for a good level of compaction in accordance with BS 1881 (1993). This portrayed the concrete mix was workable.

Table 2. Compacting factor result

\begin{tabular}{cc}
\hline Water/Cement & Compacting factor \\
\hline 0.5 & 0.82 \\
\hline
\end{tabular}

\subsection{RESULTS OF COMPRESSIVE STRENGTH AND DENSITY OF CONCRETE}

The results of Compressive strength and density of concrete are presented in Figures 2 and 3, respectively.

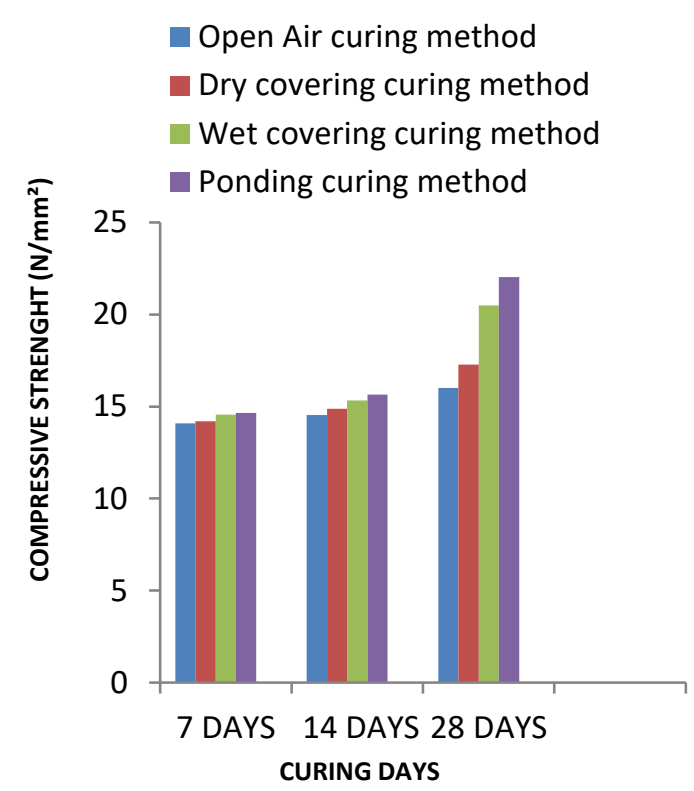

Fig. 2: Compressive strength of concrete using different curing methods

The results showed increase in compressive strength and density as curing days increases. Ponding had the highest compressive strength values of $22.04 \mathrm{~N} / \mathrm{mm}^{2}$ followed by wet covering of $20.48 \mathrm{~N} / \mathrm{mm}^{2}$, dry covering of 17.28 $\mathrm{N} / \mathrm{mm}^{2}$ and open air of $16.02 \mathrm{~N} / \mathrm{mm}^{2}$. This agrees with previous studies (James et al., 2011; Raheem et al., 2013; Idowu and Black, 2014).

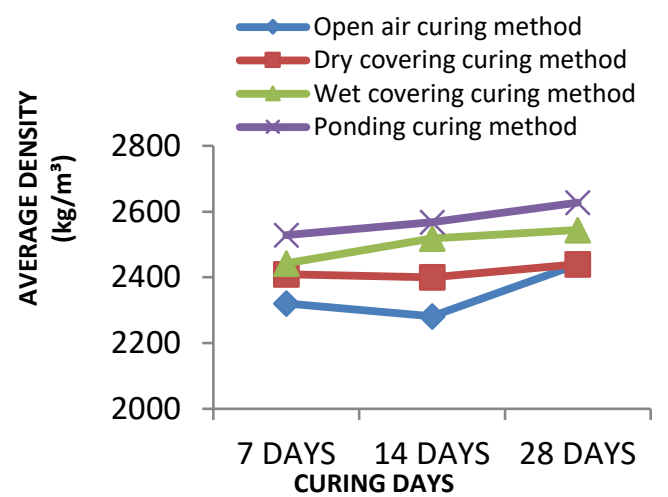

Fig. 3: Density of concrete using different curing methods
The densities of the specimens were noticed to fall within the category of normal weight concrete except for concrete cured using open air method. The results of the curing methods on density were also noticed to be directly proportional to strength. It was also noticed from the results that ponding gave the highest result for the curing period. This was due to better pore structure and of the concrete cubes. This agrees with previous work (James et al., 2011; Raheem et al., 2013)

Table 4: ANOVA of strength and density characteristics of concrete using different curing methods

\begin{tabular}{llllll}
\hline Test & $\begin{array}{l}\text { Sum of } \\
\text { squares }\end{array}$ & Df & $\begin{array}{l}\text { Mean } \\
\text { square }\end{array}$ & Fcri & Sig. \\
\hline $\begin{array}{l}\text { Between } \\
\text { groups }\end{array}$ & 2204.70 & 2 & 1102.34 & 4.25 & 0.00 \\
$\begin{array}{l}\text { Within } \\
\text { groups }\end{array}$ & 21.10 & 9 & 9.01 & & $(S)$ \\
Total & 24225.80 & 11 & & & \\
\hline
\end{tabular}

The significant difference of zero exists between the groups, which implied there is no difference between the results of the compressive strength and density of concrete. Hence, there are greater level of confidence in the experimental results.

\section{ConcLusion}

The following conclusions are drawn based on the findings from this research; adequate curing enhances the strength and density characteristics of concrete, and appropriate curing technique is an important parameter in building the strength and stability of concrete. Also, ponding curing method has greater potential of improving the compressive strength and density of the concrete. Finally, wet or sprinkling method could be adopted in in-situ construction where ponding curing techniques seems unachievable.

Based on the results of the findings from the research, further concrete curing techniques should be explored, such as: the use of polythene and jute bag. Also, curing of concrete should be enforced on construction site to improve safety of concrete structures.

\section{REFERENCES}

Amusan, G. M. and Olutoge, F. A. (2014). The effect of seawater on shrinkage properties of concrete. International Journal of Research in Engineering and Technology 2(10): 1-12.

Animesh M. (2015). Meaning of curing in civil engineering. http://www.quora.com/what-is-the-meaning-of-curing-in-civilengineering.

Aluko, O.S. (2005). Comparative Assessment of Concrete Curing Methods. Unpublished Post Graduate Diploma Thesis, Federal University of Technology, Akure, Nigeria.

Arum, C. and Alhassan, Y.A. (2005). Combined Effect of Aggregate Shape, Texture and Size on Concrete Strength. Journal of Science, Engineering and Technology.13(2), 6876-6887.

Arum, C. and Udoh, I. (2005). Effect of dust inclusion in aggregate on the compressive strength of concrete. Journal of Science, Engineering and Technology.12(2), 6170-6184. 
BS 12 (1996). Specification for Portland Cements. British Standard Institution, London.

BS 1881 (1983). Method for Determination of Compressive Strength of Concrete Cubes. British Standard Institution, London, Part 116.

BS 1881 (1993). Method for Determination of Compacting Factor. British Standard Institution, London, Part 103.

Idowu O. Black, L. (2014). Effect of improper curing on concrete performance. $34^{\text {th }}$ cement and concrete science conference proceedings, university of Sheffield, UK.

James, T. Malachi, A. Gadzama, E.W. and Anametemflok, V. (2011). Effect of curing methods on density and compressive strength of concrete. Nigerian Journal of Technology. 30(3): 14-20.

Neville, A. M. (1996). Properties of Concrete, 4th ed., USA, New York: John Wiley and Sons

Raheem, A. A.; Soyingbe, A. A. and Emenike, A. J. (2013). Effect of curing methods on density and compressive strength of concrete. International Journal of Applied Science and Technology. 3(4): 55-64

Ramezanianpour, A.A. and V.M. Malhotra, (1995). Effect of Curing on the Compressive Strength, Resistance to Chloride-Ion Penetration and Porosity of Concretes Incorporating Slag, Fly Ash or Silica Fume. Cement and Concrete Composites. 17(2), 125133.

Unnithan, R. S. and Anil, S. (2017). Review on self-curing concrete, International Journal of Engineering and Technology. 4(5): 10221024.

Wojcik, G.S., and Fitzjarrald, D.R. (2001). Energy Balances of Curing Concrete Bridge Decks. Journal of Applied Meteorology, 40(11).

Zain, M.F.M., M. Safiuddin and K.M. Yusof, (2000). Influence of Different Curing Conditions on the Strength and Durability of High Performance Concrete. Proceedings of the Fourth ACI International Conference on Repair, Rehabilitation and Maintenance, ACI SP-193, American Concrete Institute. Farmington Hills, Michigan, USA. 275-292. 